\title{
SMALL BUSINESS AND ENTREPRENEURSHIP
}

\author{
Second Edition
}

Edited by Paul Burns and Jim Dewhurst 


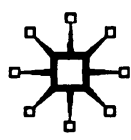

Selection and editorial matter (c) Paul Burns and Jim Dewhurst 1989, 1996

Individual chapters (in order) @ Paul Bums, Sue Birley, Paul Burns and Jean

Harrison, David Storey and Nigel Sykes, Jim Dewhurst, Martin Binks and Christine Ennew, Gondon Murray, Colin Barrow, Paut Bums, Jim Dewhurst 1996

Individual cases (in order) O lan Rae and Rifat Atun, S. A and C. J. Claridge, Jim Dewhust, Paul Bums, David Storey and Nigel Sykes, Martin Binks and Christine Ennew, ECI Ventures, Colin Barrow, Jim Dewhurst 1996

All rights reserved. No reproduction, copy or transmission of this publication may be made without written permission.

No paragraph of this publication may be reproduced, copied or transmitted save with written permission or in accordance with the provisions of the Copyright, Designs and Patents Act 1988, or under the terms of any licence permitting limited copying issued by the Copyright Licensing Agency, 90 Tottenham Court Road, London W1T 4LP.

Any person who does any unauthorised act in relation to this publication may be liable to criminal prosecution and civil claims for damages.

The authors have asserted their rights to be identified as the authors of this work in accordance with the Copyright, Designs and Patents Act 1988.

First edition 1989

Reprinted five times

Second edition 1996

Published by

PALGRAVE

Houndmills, Basingstoke, Hampshire RG21 6XS and

175 Fifth Avenue, New York, N. Y. 10010

Companies and representatives throughout the world

PALGRAVE is the new global academic imprint of St. Martin's Press LLC Scholarly and Reference Division and Palgrave Publishers Ltd (formerly Macmillan Press Ltd).

ISBN 978-0-333-64587-1 ISBN 978-1-349-24911-4 (eBook)

DOI 10.1007/978-1-349-24911-4

This book is printed on paper suitable for recycling and made from fully managed and sustained forest sources.

A catalogue record for this book is available from the British Library.

$\begin{array}{llll}10 & 9 & 8 & 7\end{array}$

$\begin{array}{lllll}05 & 04 & 03 & 02 & 01\end{array}$

Typeset by Acorn Bookwork, Salisbury, Wiltshire 


\section{MACMILLAN SMALL BUSINESS SERIES}

Series Editors: Jim Dewhurst and Paul Burns

The books in this series are designed for use by students in higher education taking courses in small-business related courses at undergraduate and post-experience level. They are also particularly useful for those studying for professional examinations and for wellinformed managers of small and growing businesses.

The books are comprehensive in scope and written by leading experts and researchers in this field. They deal with the subject in a sophisticated and rigorous way whilst still providing essential practical guidance.

\section{PUBLISHED}

Small Business Management (Third Edition) Jim Dewhurst and Paul Burns (eds)

Small Business in Europe Paul Burns and Jim Dewhurst (eds)

Small Business: The Independent Retailer Gary Davies and Kim Harris

Small Business: Production/Operations Management Terry Hill

Marketing for the Small Business Derek Waterworth

Small Business and Entrepreneurship (Second Edition) Paul Burns and Jim Dewhurst (eds) 
SMALL BUSINESS AND ENTREPRENEURSHIP 


\section{Contents}

List of Tables

vii

List of Figures

Preface to the Second Edition

ix

Notes on the Contributors

xi

xiii

1 Introduction: The Significance of Small Firms 1 Paul Burns

2 Start-up

Sue Birley

3 Growth

Paul Burns and Jean Harrison

4 Uncertainty, Innovation and Management

73

David Storey and Nigel Sykes

5 The Entrepreneur $\quad 94$ Jim Dewhurst

6 Financing Small Firms Martin Binks and Christine Ennew

7 Venture Capital

Gordon Murray

8 Franchising

Colin Barrow

9 The Business Plan

Paul Burns

10 Small Firms Policy in Europe Jim Dewhurst 
vi Contents

\section{Case Studies}

The McArdle Syringe $\quad 221$

Claridges Restaurant $\quad 232$

John Jederman $\quad 255$

Hightech Components $\quad 270$

Consetec Ltd $\quad 288$

Rollerdoors Ltd $\quad 300$

Rough Rider Seating plc 304

Franchising: Evaluating the Profit Potential of a Franchise Opportunity

Short Engineering (a) $\quad 321$

Short Engineering (b) $\quad 326$

$\begin{array}{ll}\text { Index } & 331\end{array}$ 


\section{List of tables}

1.1 Average annual registration and deregistration rates by industry, 1980-90

1.2 Regional changes by type of organisation, 1980-90 9

1.3 Net percentage change in VAT registrations by county, 1980-90

1.4 Net percentage change in the numbers of businesses registered for VAT by industry, within region, 1980-90 13

2.1 Influences on the entrepreneurial decision 22

3.1 Growth and state company characteristics 41

3.2 Competitive threats $\quad 57$

3.3 Elements of strategy $\quad 57$

3.4 The Churchill and Lewis growth model 63

3.5 Growth stage imperatives 65

3.6 Business imperatives as a firm grows 67

6.1 Financing characteristics 121

6.2 Ranking of main constraints in 1988, 1990, 1992 and 1994123

6.3 Constraints for participative and non-participative firms 124

6.4 Service quality for participative and non-participative firms

6.5 Banking relationship for participative and non-participative firms (1) 125

6.6 Banking relationship for participative and non-participative firms (2)

7.1 Total European venture capital annual investment by stage of finance, 1992

7.2 Institutional sources of capital for UK independent funds, nominal and real (1985) values

7.3 UK venture capital activity in start-up and other early stage investments as a percentage of aggregate annual investment less $\mathrm{MBO}$ values 
viii List of tables

7.4 Venture capital firms' minimum IRR requirement by investment stage for technology and non-technology investments

8.1 Percentage of franchise chains and franchisees that

8.2 The advantages of franchising

8.3 Personal franchisee characteristics required for success 177

9.1 Outline contents of business plan 


\section{List of figures}

1.1 Trends in VAT registrations and deregistrations 7

1.2 Growth in the number of businesses, by type 8

1.3 Net change in number of VAT-registered businesses, 1979-90, by industry 10

1.4 Distribution by type of business within industry 10

2.1 The credibility merry-go-round 29

2.2 Some sources of help 36

3.1 The elements of success 44

3.2 Porter's five forces 51

3.3 Long-run average cost curves 52

3.4 Competitive advantage 55

3.5 Product market matrix $\quad 59$

3.6 The Greiner growth model 62

3.7 Work effectiveness during transition 64

3.8 The process of failure in the smaller firm 69

7.1 Annual value of venture capital investment, 1981-91 136

7.2 Percentage distribution of annual investment by stage of finance, Europe and UK, 1992

7.3 Growth of management buy-outs and buy-ins, 1980-91 151

7.4 Tyebjee and Bruno's decision process model of venture capital activity 153

7.5 'A competitive forces' analysis of the UK venture capital industry in $1993 \quad 159$

$\begin{array}{lll}9.1 & \text { The planning process } & 181\end{array}$ 


\section{Preface to the second edition}

This book is about small business, warts and all. It is about new businesses, growing businesses, businesses that go nowhere and businesses that fail. It is also about the owner-managers that run these firms. Most interesting of all, it is about entrepreneurs, that small group of owner-managers who try - and sometimes succeed in growing their business and making a success of it.

It is aimed particularly at those students of business that are interested in the way the majority of firms actually work. It is suitable for all students taking courses on small business and entrepreneurship in universities and colleges, as well as those entrepreneurs interested in their own endeavours. It is primarily a 'why to do it' text and is designed to be used with its sister text, Small Business Management (now in its third edition), which is more of a 'how to do it' text. The book has developed out of MBA (Master of Business Administration) courses at Cranfield University School of Management, and Warwick Business School UK. MBA students seem fascinated by entrepreneurs and many come to a business school harbouring a deep-seated desire to set up their own business. Sadly, few ever do.

The sheer diversity and complexity of the issues facing the entrepreneur in business today is such that no one person can ever claim to be an expert in all the areas. This book brings together a large number of contributors, all experts in their respective fields. This second edition has many changes and many new contributors. There is a greater emphasis on the way firms develop and the problems small firms face in raising finance. Even chapters you may recognise from the last edition have been extensively rewritten. The structure of course that this book is designed to support involves some 'talk- 
at' sessions but also case analysis. This edition of the book has many new case studies, this time with questions to be addressed in class. Inevitably, however, any course on entrepreneurship must involve a talk by an entrepreneur on 'what it is really like'. Our experience is that this will be the highlight of the course. No matter how good the teacher, there is no substitute for the real thing - somebody who did it.

The book retains a chapter on the business plan, now revised and updated. Part of the course work on many small business courses involves the preparation or review of a business plan on an idea for a business start-up. Ideally students should be asked to prepare a plan on an idea of their own that they think has some commercial potential. Preparing the plan forces them to be creative and entrepreneurial. It also takes them beyond the ideas stage and forces them to crystallise their ideas, write them down on paper and show how they can be made to happen. This is not only creative, but also an excellent management discipline. It integrates all the functional areas of management that, sadly, all too often are taught separately. We normally insist that students present their plans to fellow students so that each can learn from the other's endeavours

In the final analysis, any course on entrepreneurship must challenge students to think entrepreneurially. It must make them realise how the needs of the owner-manager and the business are intertwined. It must make them address issues in a multidisciplinary way. But, most of all, it must be fun and interesting.

PAUL BURNS JIM DEWHURST 


\section{Notes on the contributors}

Colin Barrow is Head of Enterprise Group, Cranfield, and nonexecutive chairman, Midland Bank, Thames and Chiltern Venture Capital Fund. He is the author of a number of books and guides on franchising, small businesses, etc.

Martin Binks is Senior Lecturer in Economics at the University of Nottingham, specialising in entrepreneurship and the financing of SMEs. He is visiting professor to the Clairmont Graduate School in California, council member of the Small Business Research Trust and associate editor of The Journal of Small Business Finance.

Sue Birley is Professor of Management in the field of entrepreneurship at the Management School, Imperial College of Science, Technology \& Medicine, and is chairman and co-founder of Newchurch \& Company.

Paul Burns is Chairman of Design for Learning Ltd and Director of the 3i European Enterprise Centre. He was Professor of Small Business Development at Cranfield University and was founding President of the Institute for Small Business Affairs. Previous books include Small Business Management (1993) and Business Finance - A Pictorial Guide (1994).

Jim Dewhurst is a chartered accountant. His extensive commercial experience includes periods as company secretary and financial director. He currently lectures on the Open Studies Programme at the University of Warwick. He is the author of a number of books, 
the two most recent in this area being Business Mathematics and Small Business Management.

Christine Ennew is Professor of Marketing in the School of Management and Finance at the University of Nottingham. Her research interests lie in the area of financial services and particularly on the relationships between banks and small businesses. She is the author of a variety of marketing-related books and is the associate editor of the International Journal of Bank Marketing.

Jean Harrison is Managing Director of Design for Learning Ltd. She was deputy director of the Small Business Programme at Cranfield University. She is a former director of the Institute for Small Business Affairs, and has lectured and written extensively in the areas of small business and entrepreneurship.

Gordon Murray is Lecturer in Marketing and Strategic Management at Warwick Business School, University of Warwick. He has published widely in the area of venture capital finance in both practitioner and academic journals. Dr Murray is particularly interested in trans-Atlantic comparisons of early stage venture capital support. $\mathrm{He}$ is also a non-executive director of a venture-backed Anglo-American high technology start-up company.

David Storey has degrees from Hull, Oxford and Newcastle Universities. He is a Professor and the Director of the SME Centre, University of Warwick. He is the author of Understanding the Small Business Sector (1994).

Nigel Sykes joined the SME Centre, University of Warwick, in 1988 and is currently Senior Teaching Fellow. He was formerly Enterprise Agency Director and Community Programme Manager, Birmingham Chamber of Commerce. 